\title{
Household behavior to manage electricity consumption after the tariff increase
}

\author{
Edward $^{1}$; Johannes ${ }^{2 *}$ \\ 1) Magister Management, Postgraduate Program, Universitas Jambi, Indonesia \\ 2) Doctoral Program, Postgraduate Program, Universitas Jambi, Indonesia \\ *To whom correspondence should be addressed.Email: johannes@unja.ac.id
}

\begin{abstract}
The event of price electricity increases in Indonesia since 2017 is expected to encourage households to take planned actions on electricity consumption. Hence, this study is intended to reveal the behavior of households to support electricity consumption saving program of the household consumers. By using the Theory of Planned Behavior approach, it is known that: 1) the respondents realize the importance of saving electricity consumption through their behavior; varied regulating electricity equipment, providing household appliances, the use of electricity saving devices. 2) However, households are hindered by psychological constraints about their uncertainty rewards. 3) There is no evidence that households take planned actions in order to use electricity more economically. Thus, it is recommended that PLN (State Owned Electricity Corporation) continue to carry out integrated communication over household consumer about practices to save electricity. It could be conducted by introducing values established, including rewards that can be adopted by households as part of education to the households.
\end{abstract}

Keywords: Electricity consumption, Household management, Household saving behavior JEL Classifications: D12, D22, D90

\section{INTRODUCTION}

Electricity scarcity in Indonesia still occurs where one of the reasons is income increase that causes demand increase. Until the beginning of 2018 electricity consumption at the household level is averagely $1,021 \mathrm{kWh}$. It is under the target on the future of 1,129 $\mathrm{kWh}$ per capita in 2018. Additionally, it also caused by the uneven levels of electrification between regions (Anonymous, 2018). Electricity fulfillment mainstreaming is focused on the supply side. So, the solution is mainly finding and exploring various sources such as gas and earth oil, Methane Coal bed, coal, geothermal energy, new and renewable energy, mineral natural resources and biological resources (Anonym, 2013).

To consider the problem of electricity scarcity Suryanto (2013) suggests three principle programs, namely availability, accessibility, affordability (acceptability). Hence National Policy to overcome scarcity is provides a 35,000 MW electricity procurement that requires high-cost construction and facilities throughout Indonesia. In this case, the electricity fulfillment strategy that focuses on supply ignores user potential savings solution. Tough potential saving behavior of electricity users is an important part of managing electricity needs both in the short and long term (Anonym, 2015).

Additionally, in order to solve supply shortages, Indonesia also faced with an inappropriate subsidy policy for the recipients are not the right citizens. So, in 2017 the government issued a policy of withdrawn subsidies, especially for household's user of 
450 and $900 \mathrm{KwH}$ customers which increases household monthly payment. Government witdrawl policies on electricity however still consider its social functions, pay attention to disadvantage poor groups. Therefore, PLN (State Owned Electricity Corporation) in cordinater with TNP2K, the agency that is authorized to manage poverty data in Indonesia, provide recommendations among these poor people who are still given electricity subsidies, especially for users of 450 and $900 \mathrm{KwH}$ (Anonym, 2017).

Households involvement on electricity consumption must be considered as one of scarcity solution. The right intervention makes theirs reason is not only based on the rationale considerations but also based on customer emotion. Otherwise, emotion is derived from household value adopted. Those aspects then could be considered into factors that determines affection, behavior, and control in choosing the alternative when stimulus is coming.

These three components is widely used to explain and predict behavioral intentions and consumer behavior that was initiated by Ajen (1991), then followed in (2002). It is known as PTB (Planned Theory Behavior) which is widely used to explain consumer behavior due to the stimulus.

Accordingly, electricity-saving, energy-saving behavior are subjects that have different understanding but have the same goal. These behaviors occur in response of electricity prices rising. In line with it, behavior indicators that can be used for those concepts measured is known as a hybrid approach. They are 1) LED lights used, 2) LED TVs used, 3) Electricity-saving air conditioners, 4) time to use drying machines, 5) electricity-saving on ironing, and 6) pull out the plug (Untoro, Gusmedi \& Purwarsih, 2014). Additionally, it is also including behavioral actions namely, 1) deciding the handler of goods that do not use electricity, 2) communicating between household members in terms of the need to save electricity and 3) used special sleep lights (Anonym, 2015; Johannes \& Pasaribu, 2016).

Managing consumption and choosing product used is influenced by value adopted. According to Anana \& Nique (2007) values differ from attitudes where attitudes are more positive or negative, but values lead to the desired conditions in a social order so that it is believed to be a determinant of behavior. The value personal adopted is believed affect his/her consumer behavior. Kao \& Tu (2015) show that values related to environmental values influence a person's attitude in consuming electricity, because the changes in climate hot and cold affect the choice of heating devices. The same thing was also found by Eskeland \& Medakas (2010) which states that climate change affects electricity demand.

Behavioral research related to electricity consumption behavior is still rarely conducted particurally after subsidies withdrawl. It is noticed related researchs: Destyasa, Setyanto \& Farela (2013) revealing provider services including the implementation of a model of service in customer satisfaction, Murtagh, Gatersleben \& Uzzell (2014) examined behavior difference in terms of smart electricity signals, Ogwumike, Ozughalu \& Abiona (2014) examined the determinants of energy used at the household level, and Johannes, Sari \& Amalia (2015) examined the customer perceptions of smart electricity usage. Hence, the research question is: how is consumer behavior intension on electricity consumption after tariff increase.

\section{LITERATURE REVIEW}

Consumer behavior according to Schiffman \& Kanuk (2010) focuses on explaining the consumer behavior to seek information, consume, use goods and services, and stop using them. In this connection, the increase in electricity prices could be observed through consumer behavior changing on their electricity daily usage. 
To the households customer electricity prices increase encourages them to manage consumption through two main actions: first, choosing electricity-saving household appliances, and secondly through managing appropriate use to pay less.

TPB was developed by researchers to predict consumer behavior as the stimulus come. It is used widely in different fields because of its dynamics and flexibility. Avci, \& Yayli (2014) use it for a work climate that employees in one organization. While Sentosa. \& Nik Mat (2012) combine it with Technology Acceptance Model (TAM) to get broader picture of readiness to accept and intention of respondent's behavior in using internet purchases

Based on TPB, customer intends to the certain direction due to their own cognition. Cognition then, is followed by attitudes, subjective norms and perceptions of behavioral control. Attitudes can be positive or negative towards certain thing, how one accepts them. While subjective norms relate to rules that apply individually to a certain thing. This rule is established because supported by customer value adopted (Nelson, Janzen, Trainor \& Ochocka, 2008). While the perception of behavioral control concerns how one associates himself with the social climate (environment) that occurs (Ajzen, 1991; Ajzen, 2002).

Furthermore, it was explained that behavioral intention is determined by a combination of attitudes, subjective norms, and behaviors that are perceived as control. Accordingly, TPB was intended to understand the possibility why people participated to certain conditions.

TPB was firstly established by Ajzen (1991) who extend his own intention behavioral model to be powerful. It is recognized as an open model that can be applied in various field and even added variables to the model according to academic requirements. De Visser \& McDonnell (2008) used TPB to explain the acceptance of parents towards vaccination behavior while Chipulu, Marshall, Ojiako \& Mota (2018) use it to explain consumer acceptance of multinational companies, and Pavlou \& Fygenson. (2006) used TPB to predict customer adoption on electronic commerce. Many researchers use it in different disciplines because logic and requirements are easy to understand.

The subsidy withdraw however is a policy that expect customers to do electricity saving programs. Not only because he will pay cheaper, but it encourages them consciously provide benefits to others. This is possible because the customer has, adopts the value every time he consumes goods and services. Values can be found because of the experience of individual years of functional benefits and social benefits of goods and services consumed. Johannes \& Pasaribu (2016) reported that in terms of smart electricity customer, they believe from the begining that using smart electricity will provide benefit because users can manage their own use. However, they did not receive the benefit because they did not believe that the price, they paid would be cheaper. Though the user has been involved in many efficient behaviours. This means that the behavior of electricity use is not only intended to be related to the amount of monthly fees to be charged, but also related to the placement of values by users (Anana, \& Nique, 2007).

\section{METHODS}

The study was conducted with survey method where the population is household customer. Sampling was chosen by two stages, the first stage was chosen sub-districts from 11 sub-districts in Jambi city, the second the households were selected from the list of residents in the chosen sub-districts. Thus, unit analysis is the customer household. Sample size determination follow Naresh \& Birks (2007) rules that recommend sample size for new product test minimally is 200 units. Primary data collected is related to the saving behavior of electricity use using tools and their actions in response to the increase in electricity prices. Variable measurement uses a Likert scale with five measurement 
points. The analysis tool uses the TPB approach where the research variables are tested using a regression analysis approach followed by Path analysis.

\section{RESULT AND DISCUSSION}

\section{Result}

PLN as a state-owned company is responsible for meeting all electricity needs. In carrying out its business, equity considerations remain a priority. So, when electricity scarcity emerges, one of the programs is to encourage customers to save electricity through household's management and use home appliances that save electricity. Hence, Johannes \& Pasaribu (2017) suggest PLN to encourage households to be involved in electricity management so that savings can be obtained both at the household level and macro level.

Brief description of sample is described in Table 1. Several qualitative tendencies through the observations and in-depth interview results are explain as follow. In the future the percentage of smart electricity users will be larger because of PLN's internal policies that prioritize them. In line with it, it is argued that smart electricity users will be more responsive to price increases because household is informed through the appliance, monitor that installed. In contrast, customer who paid through auto debit will be less responsive to the tariff increase, because it is only known when they check banking records. In contrast with users who make payments through cash, they will be more responsive to price increases for they have receipt mouthly. Furthermore, the use of electricity-saving tools has not been widely used. The reason is that customers still do not believe that the device can reduce monthly payment.

Table 1. Brief description of sample (n: 205 units)

\begin{tabular}{|c|c|c|c|}
\hline No & Description & Frequencies & Percentage \\
\hline \multirow[t]{6}{*}{1} & Education & & \\
\hline & Primary School & 17 & 8,3 \\
\hline & Junior School & 12 & 12,5 \\
\hline & Senior High School & 55 & 26,8 \\
\hline & Diploma & 12 & 5,9 \\
\hline & Postgraduate (S1, S2\&S3) & 109 & 53,2 \\
\hline \multirow[t]{3}{*}{2} & Kinds of electricity & & \\
\hline & - Conventional Electricity & 139 & 67,8 \\
\hline & - Smart Electricity (Prepaid electricity) & 66 & 32,2 \\
\hline \multirow[t]{3}{*}{3} & Habit to buy pulse of prepaid electricity & & \\
\hline & - Unplanned & 20 & 30,8 \\
\hline & - Planned & 45 & 69,2 \\
\hline \multirow[t]{3}{*}{4} & Habit for conventional payment & & \\
\hline & - Auto debit & 10 & 7,1 \\
\hline & - Cash etc. & 130 & 92,9 \\
\hline \multirow[t]{8}{*}{4} & Kinds of Electricity Categories (KwH) & & \\
\hline & - 450 & 8 & 3,9 \\
\hline & - 900 & 35 & 17,1 \\
\hline & - 650 & 1 & 0,5 \\
\hline & - 1200 & 3 & 1,5 \\
\hline & - 1300 & 111 & 54,1 \\
\hline & - 2200 & 46 & 22,4 \\
\hline & - $3500-5500$ & 3 & 1,5 \\
\hline \multirow[t]{3}{*}{5} & Energy saver equipment & & \\
\hline & - Yes & 17 & 8,3 \\
\hline & - No & 188 & 91,7 \\
\hline
\end{tabular}

Source: Primary data, 2018 
The results of statistical tests and path analysis using SPSS for Amos 21. The results obtained from the data processing are presented in Figure 1.

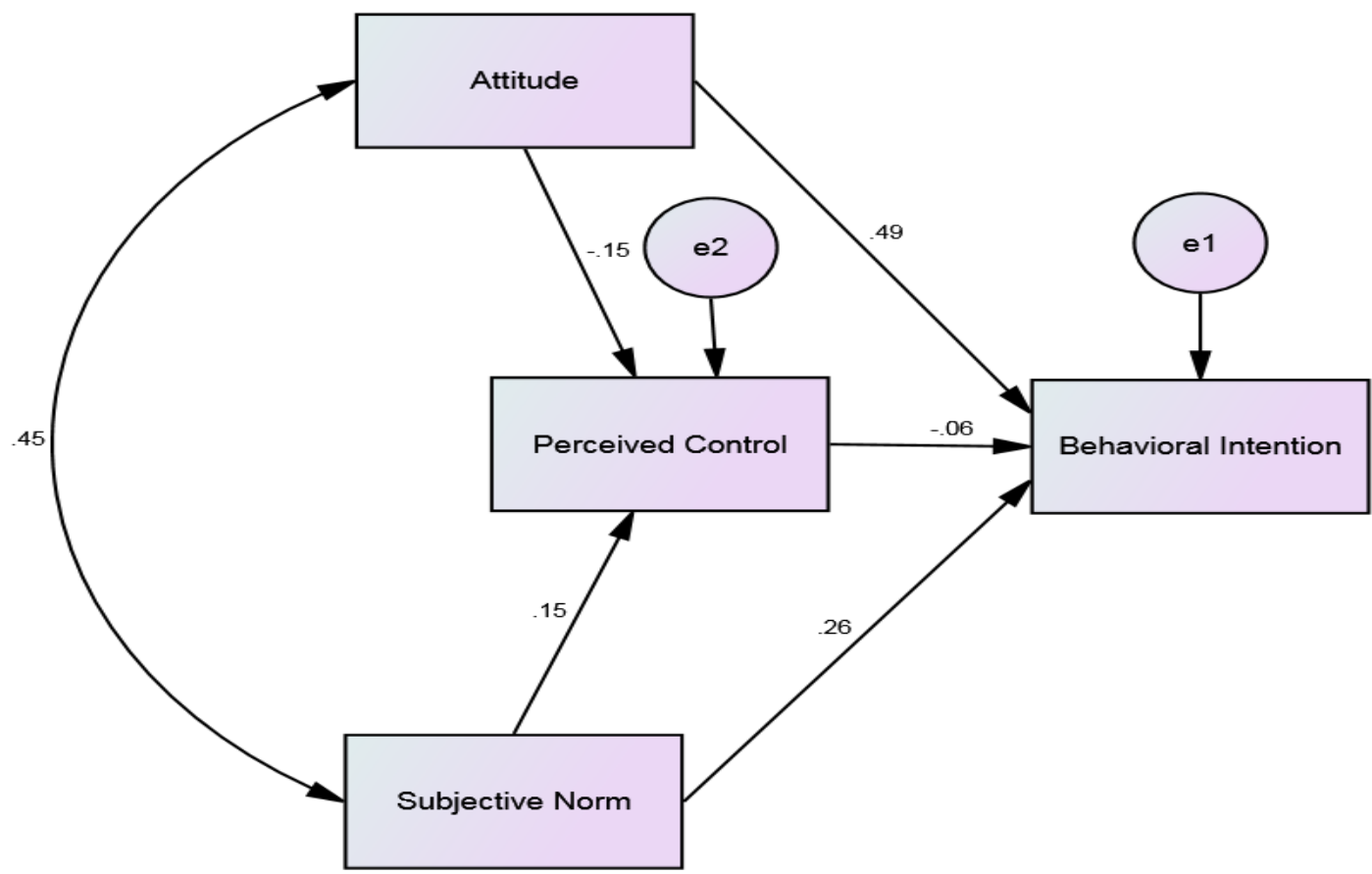

Figure 1. Path Analysis result of electricity management at the household level after tariff increase

As can be seen in Figure 1, using path analysis it is shows the results of the relationship between Attitude (AT), Subjective Norm (SN) to Perceived Control (PC), and then the relationship between PC to Behavioral Intention (BI). Furthermore, as presented in Figure 1, the significance of the relationship between the variables indicated by the $P_{\text {value }}$ is shown in Table 2 below.

Table 2. Significance test results between TPB variables on electricity savings intention

\begin{tabular}{lll|rrrrr}
\hline & & & Estimate & S.E. & C.R. & P & Label \\
\hline 1) Perceived (PC) & $<---$ & attitude (AT) & -.160 & .085 & -1.877 & .060 & par_5 \\
2) Perceived (PC) & $<---$ & subjective (SN) & .172 & .087 & 1.976 & .048 & par_6 \\
3) Behavioral (BI) & $<---$ & perceived (PC) & -.063 & .058 & -1.095 & .274 & par_1 \\
4) Behavioral (BI) & $<---$ & attitude (AT) & .566 & .070 & 8.103 & *** & par_2 \\
5) Behavioral (BI) & $<---$ & subjective (SN) & .313 & .072 & 4.377 & *** & par_3 \\
\hline
\end{tabular}

The test results of the five hypotheses proposed as depict in Figure 1 are explained as follows.

1) $\mathrm{H}_{1}$ proposed that $\mathrm{AT}$ has positive relation to the PC is not accepted. The attitude of saving electricity consumption does not have a relationship with the obstacles to implementing it.

2) $\mathrm{H}_{2}$ proposed that $\mathrm{SN}$ has positive relationship to the $\mathrm{PC}$ is received with a value of $\mathrm{P}$ (.048). This shows that the norms adopted by household have a positive relationship to the PC (which is considered an obstacle) by the respondents.

3) $\mathrm{H}_{3}$ proposed that $\mathrm{PC}$ has positive relation with $\mathrm{BI}$ is not accepted with $\mathrm{P}$ value (.274) with a correlation coefficient of -.06. This shows that the constraints are inversely related to action. That is, the higher the level value (PC), the less action will be. 
4) $\mathrm{H}_{4}$ proposed that AT has positive relation with $\mathrm{BI}$, is accepted, and it is highly significant.

5) Finally, H5 proposed that SN has positive relationship with BI, H5 is acceptable.

\section{Discussion}

The aspect of cognition, attitudes and perceptions is important to understand consumer behavior. The three concepts are expected to be aligned in the direction faced by the electricity saving program. Cognition involves knowledge of objects related to the presence of stimuli while attitudes are based on affections that show a tendency. In this case, price increase caused customer to use electricity economically (Cebulla, R., J (2010). So, the role of PLN is needed to campaign ways and benefits to be obtained from the use of electricity more efficiently collectively (Galis \& Gyberg, 2011).

Regarding to the management of electricity usage, consumer involvement is important to succed the firm's goal (Olson \& Peter, 2010). It could be carried out with the good understanding and clarity of benefits received to the customers. This benefit is categorized as functional and emotional. Functional relates to practical benefits because it has or uses something, while emotional benefits are due to the value order adopted by the customer. Values are known in the TPB approach as Subjective Norms, norms or rules adopted subjectively that are shared at the family level. So that, when there is an external stimulus, the value of being a differentiator between individuals will determine. Values will be seen both for individual and social interests (Hussaini, M., and Abdul, N., 2014)

Additionally, Ogwumike, Ozughalu, \& Abiona (2014) revealed that factors influence energy use at the household are parental education, per capita expenditure, and the size of household members. It is also supported by Svendsen (2011) who suggests that consumer engagement must be part of the strategy. Thus, customer involvement is strategic factor for success of the electricity use saving program (Fatima \& Razzaque, 2013; Espejel, Fandos \& Flavian, 2009).

However, based on TPB, perceived control shoulde be considered as of important thing to arrange program. The role of PLN as a provider in this case is to provide integrated communication about the benefits of saving electricity usage starting from: 1) turning off unneeded lights, 2) removing power outlets, 3) choosing low Watt household appliances, up to the use of electricity saving devices. That was confirmed by Yuliati, \& Nurasrina, (2012) who campaigned for the need for electricity-saving behavior at the household level. The way that is relevant is to promote value, even personal value, towards the practice of economical use of electricity where the benefits will be received more widely by society (Anana \& Nique, 2007).

\section{CONCLUSION AND RECOMMENDATION}

\section{Conclusion}

Attitude and Subjective Norm are things that play an important role in determining Behavioral Intention to manage electricity usage. Things that is an obstacle is expressed in the form of Perceived Control, including consumer uncertainty about the respondent's actions whether to provide benefits or not. There are indications that consumers do not feel any functional and not beneficial benefits from their actions. Perceived Control, however, is an opportunity for the PLN to direct customer actions with one principle, without having to reduce the use of Watt electricity used, consumers remain in the electricity conditions that are met. 


\section{Recommendation}

To make save electricity program be effective, PLN should build intensive communication and ensuring customers received the benefit. PLN continue to carry out integrated communication over household consumer about practices to save electricity. It could be conducted by introducing values established, including rewards that can be adopted by households as part of education to the households.

\section{REFERENCES}

Ajzen, I. (1991). The theory of planned behavior. Organizational behavior and Human Decision Processes, 50(2), 179-211. doi:10.1016/0749- 5978(91) 90020-t

Ajzen, I. (2002). Perceived behavioral control, self-efficacy, locus of control, and the Theory of Planned Behavior. Journal of Applied Social Psychology, 32(4), 665683. doi:10.1111/j.1559-1816.2002.tb00236.x

Anana, E. D.S \& Nique, W.M., (2007). A professional category positioning: the role of personal values and their influence on consumer perception. Journal of Database Marketing \& Customer Strategy Management, 14(4), 289 - 296.

Anonym. (2013), Indonesia power report. Business Monitor International, United Kingdom

Anonym (2015), Keuntungan listrik pintar, retrieved from http://www.pln.co.id/ blog/keuntungan listrik Pintar, (Accessed 10 Mei 2015)

Anonym. (2017), Briefing subsidi energi Indonesia, sebuah kajian dwi-bulanan tentang kebijakan subsidi energi Indonesia dan pasar energy. Global Subsidies Initiative, International Institute for Sustainable Development (IISD), Jakarta

Anonym. (2018). Konsumsi listrik per kapita Indonesia masih tertinggal, Kompas, 11 Januari 2018.

Avci, C \& Yayli. (2014). Examining safety behavior with safety climate and the theory of planned behavior. International Journal of Arts \& Sciences, 7(4), 611-626.

Cebulla, R., J. (2010). Recent evidence on determinants of per residential Customer electricity consumption in the U.S.: 2001-2005, Springer Science+Business Media, LLC 2010, 925-936

Chipulu, M. Marshall, A., Ojiako, U \& Mota, C. (2018). Reasoned ethical engagement: Ethical values of consumers as primary antecedents of instrumental actions towards multinationals. Journal of Business Ethics, 147(1), 221-238. doi:http://dx.doi.org/10.1007/s10551-015-2994-5

De Visser, R., \& McDonnell, E. (2008). Correlates of parents' reports of acceptability of human papilloma virus vaccination for their school-aged children. Sexual Health, 5(4), 331. doi:10.1071/sh08042

Destyasa, E.W., Setyanto, N.W \& Farela, C. (2013). Analisis Kualitas Jasa Listrik Prabayar Dengan Mengintegrasikan Metode Service Quality (Servqual) Dan Quality Function Deployment (QFD) (Studi Kasus PT.Perusahaan Listrik Negara (Persero), Tbk.). Jurnal Rekayasa dan Manajemen Sistem Industri, 1(2), 218-228.

Espejel, J., Fandos, C. \& Flavian, C. (2009). The Influence of consumer involvement on Quality Signals Perception. British Food Journal, 111(11), 212 - 1236

Fatima, K.J., Razzaque, A., M. (2013). Roles of Customer Involvement in Rapport and Satisfaction. Asia Pacific Journal of Marketing and Logistics, 25(3), 452-471

Galis V. \& Gyberg P. (2011). Energy as a Collective the Case of Colonia: Student Dormitories at a Swedish University. Energy Efficiency, 4(2), 303-319 
Hussaini, M. \& Abdul, N. (2014). Human behavior in household energy use and the implications of energy efficiency delivery. International Journal of Energy Sector Management, 8(2), 230-239

Johannes \& Pasaribu, J. (2016). Household involvement on smart electricity management: is it potential for energy saving? International Journal of Economics, Commerce, and Management, IV(4), 1185-1196

Johannes, Sari, N. \& Amalia, W.L. (2015). Persepsi Pelanggan Terhadap Listrik Pintar, Jurnal Dinamika Manajemen, 2(3), 160-168.

Kao, T. \& Tu, Y. (2015), Effect of green consumption values on behavior: the influence of consumption attitude. International Journal of Arts \& Sciences, 8(8), 119-130.

Murtagh, N., Gatersleben, B. \& Uzzell, D. (2014), Differences in energy behavior and Conservation Between and Within Households with Electricity Monitors. PloS ONE, 9(3), 1-12

Nelson, G, Janzen, R, Trainor, J. \& Ochocka, J. (2008). Putting value into practice: Public policy and the future of mental consumer-run organization. American Journal of. Community Psychology, 42(1), 192-201

Ogwumike, F.O, Ozughalu, U.M \& Abiona, G.A. (2014). Household energy use and determinants: Evidence from Nigeria. International Journal of Energy Economics and Policy (IJEEP), 4(2), 248-262

Olson J. \& Peter P. (2010). Consumer Behavior \& Marketing Strategy. $9^{\text {th }}$ ed. Mc. Graw Hill

Pavlou, \& Fygenson. (2006). Understanding and Predicting Electronic Commerce Adoption: An Extension of the Theory of Planned Behavior. MIS Quarterly, 30(1), 115-143. doi:10.2307/25148720

Schifman, L.G. \& Kanuk, L. L. (2010). Consumer Behavior, Pearson Prentice Hall, United States of America

Sentosa, I.\& Nik Mat, N.K. (2012), Examining Theory of planned behavior (TPB) and Technology Acceptance model (TAM) in Internet purchasing using structural equation model. Journal of Arts, Science \& Commerce, III, 2(2), 62-77

Suryanto, Y. (2013). Konsumsi energi listrik dan model pertumbuhan ekonomi di Indonesia: Aplikasi dan model. Bappenas, Jakarta

Svendsen, M.F. (2011) Marketing Strategy and Customer Involvement in Product Development. European Journal of Marketing, 45(4), 513-530

Untoro, J, Gusmedi, H \& Purwarsih, N (2014). Audit Energi dan Analisis Penghematan Konsumsi Energi pada Sistem Peralatan Listrik di Gedung Pelayanan Unila. Jurnal Rekaysa dan Teknologi Elektro, 8(2), 93-104

Yuliati, L.N. \& Nurasrina, I. (2012). Pesan kesadaran dan Perilaku Hemat Listrik Rumah Tangga. Jurnal Ilmu Keluarga dan Konsumen, 5(1), 88-95 